\title{
Retirement Options and their Consequences for Small Business Owners
}

\author{
Valeria Alterman (University of Miami) \\ Ariane Froidevaux (University of Texas at Arlington)
}

KEYWORDS: Family Business, Succession.

Pierre, a Swiss bakery co-owner for four decades, left his business behind when he reached age 65, the eligible retirement age in Switzerland. He was looking forward to leaving seven-day workweeks behind and spending more time with his wife and grandchildren. He left the bakery to his younger cousin and felt confident it was in good hands.

But Pierre (not his real name) couldn't stop thinking about his business and about baking, which continued to be a passion. He would wake up as if he needed to go to work and visit the bakery several times a week. His high psychological ownership of the business didn't shut down when he turned over the keys to his successor.

Pierre's experience illustrates just part of the transition problems faced by departing small business owners and the stewards they leave behind to move their businesses forward. As a growing number of countries have aging populations, these transitions are sure to intensify. Our research examines different retirement options for small business owners in detail, and provides a framework for determining the optimal transition plan.

\section{Aging Demographics}

As a growing number of countries face the demographic challenge of an aging population, much attention is devoted to the retirement of older workers. Their exit from the workforce will leave many organizations struggling to replace their talent and knowledge. This is especially true for small businesses. Can the business continue if the owner retires? How can owners best prepare the business for their exit? And when should they simply sell or liquidate their business? In our research, published in the scientific journal "Work, Aging and Retirement" (Alterman et al., 2020), we seek to answer these questions by studying the retirement process of small business owners, who not only have to manage their own separation from work but also the options for the future of their business. This article provides an overview of our framework to help businesses and owners analyze the options and understand the factors that drive their decisions.

First, we present four specific options that consider different alternatives for a business when the owner exits: family succession, retirement from management while maintaining ownership, independent sale, and liquidation. Second, we discuss unique antecedents (factors) that are likely to shape business owners' retirement decisions (Wang \& Shultz, 2010; Wang, Henkens, \& van Solinge, 2011). Finally, we examine how each choice may affect business owners' psychosocial and financial well-being as they adjust to retired life. (Alterman et al., 2020).

\section{Four Retirement Decision Options}

Our model presents four decision options for small business owners to separate from their business as they retire. These retirement options represent more of a process than a single event, and each can be categorized by how closely the business owner stays involved (DeTienne, 2010); that is, the "proximity" of the business to the individual once the decision has been made. In order from closest to farthest proximity, the retirement options include: family succession, retire from management while maintaining ownership, independent sale, and liquidation.

- Family succession - In this process, business owners transfer the ownership of the business to family members (Sharma et al., 2003). Although a highly preferred option, it is adopted only about $20 \%$ of the time (Knot, \& McGrath, 2004). When family succession does occur, only a small proportion of the businesses survive
Copyright $@ 2021$ The Authors. Entrepreneur \& Innovation Exchange is published at EIX.org. This is an open access article under the terms of the Creative Commons Attribution-NoDerivs License, which permits use and distribution in any medium, provided the original work is properly cited and no modifications or adaptations are made. View EIX.org Authorship Terms at https://eix.org/terms
FamilyBusiness 
beyond the second or third generation of family ownership (Lee et al., 2003).

- Retirement from management while maintaining ownership - Some small business owners decide to retire without relinquishing ownership of the business. This typically means hiring someone from outside the family to manage the business (Gómez-Mejía et al., 2011). Although this is an attractive option for many business owners, it represents a partial exit from work and only a short-term solution, as the owner will still need to decide when and how to relinquish ownership of the business down the road.

- Independent sale - Selling the business to an individual or another firm gives the retiring owner a say in who buys the business (DeTienne, 2010). However, it may be difficult and time-consuming to find the right buyer, especially if an owner is picky about the parties involved in the transaction. Interestingly, although $53 \%$ of owners expect to transition to some form of external buyer (Exit Planning Institute, 2013), only about 20 to $30 \%$ of businesses that go to market actually sell (Forbes, 2017).

- Liquidation - Terminating the business is likely the least desirable option for small business owners because of the emotional costs involved with liquidation (Mitchell, 1994). Once liquidated, business owners have nothing more to show for their hard work and time invested in their business. Nevertheless, this option is adopted $44 \%$ of the time (Balcaen et al., 2012).

\section{What Factors Relate to Each Option?}

To better understand small business owners' retirement decisions, we looked at the key antecedents (existing factors) that drive those decisions. We group these factors into three levels of predictors: individual, relational, and business.

- At the individual level, we focus on small business owners' psychological possessiveness of their businesses (Pierce et al., 2001). In fact, small business owners often see their businesses as extensions of their personal identity, which connects them very closely to the business, its operations, and its future. Overall, individuals who invest more of themselves in the business have higher degrees of psychological ownership (DeTienne, 2010). These owners are more likely to choose a retirement option that allows them to keep their firm proximately close.

- At the relational level, two factors impact a small business owner's retirement decision: business-related family conflict, and the presence of a potential successor. First, business-related family conflict often arises when key players have different needs and goals for the business (Raymo \& Sweeney, 2006). This leads to a struggle within the family for ownership control of the firm. When this happens, small business owners may be more likely to choose an option that puts some distance between themselves and their business after they retire (e.g., a low proximity option). For example, to prevent their children from fighting over control of the firm, business owners may prefer to sell or liquidate the business. Second, the presence of a potential successor is a necessary condition for small business owners interested in the family succession retirement option (Neubauer, 2003). The availability of a successor is likely to result in options that let the retiring owner stay close to the business after retirement.

- At the business level, two factors can influence small business owners' retirement decision: the business's structure, and financial value. First, a business structure that includes non-family business partners often makes it more difficult for owners to pass the business to relatives. In these cases it's more likely that retirement decisions will be made to maximize an owner's financial income (often an independent sale or retiring from management but continuing ownership) (DeTienne et al., 2015). Second, the business's financial value can be an important factor in determining whether selling the business is a good option (Morris et al., 2018). If the company has high financial value, a retiring owner could maintain ownership, sell it to reap a cash windfall, or pass it along to a family member to maintain and grow the family's financial wealth.

\section{Consequences in Retirement}


Because work strongly shapes a person's identity, resources, and sense of value (e.g., income, recognition, time structure, relationships), adjusting to retirement can be hard for many small business owners. To tie together the unique predictors and retirement options with potential consequences, let's look at how the four retirement/business exit options impact the owner's financial and psychosocial well-being.

Financial well-being: The retirement decisions small business owners make may allow them to gain sufficient financial resources to support their lifestyle during retirement. This will in turn impact their post-retirement financial well-being. For instance, an independent sale may help business owners reach their financial goals if they are willing to wait for the right buyer, and retirement from management while maintaining ownership may be a second alternative for them to continue having a source of income during retirement. Family succession may limit a small business owner's financial well-being unless he or she sells shares to successors or draws earnings through dividends or serving on the board of directors. Liquidation generally results in less financial gain in comparison to the sale of a business (Wennberg et al., 2010).

Psychosocial well-being: Drawing from theories of continuity and adjustment (Atchley, 1989), we propose that options that allow small business owners to maintain a similar level of business activity and identity post-retirement compared to pre-retirement will result in the highest level of psychosocial well-being. Both family succession and retirement from management while maintaining ownership allow a business owner to continue having access to business dealings, therefore providing better emotional adjustment after retirement. In comparison, independent sale and liquidation may result in an abrupt change for a small business owner, creating a sense of psychological loss and questions about identity, thus lowering their psychosocial wellbeing.

\section{Case Study}

Pierre, the Swiss bakery co-owner, told us he retired at 65 "to finally have a real stop, after running a business with no real down times -- not even on evenings or weekends -- to spend more time with my wife and with my grandchildren." (See Pierre's identity transition analysis in Froidevaux, 2018)

Pierre's sense of psychological ownership was high. He explained that during his entire life he had worked long and hard to help the business thrive and become financially stable, but new competitors in the market had made this increasingly difficult. Pierre nonetheless remained passionate about baking. He chose the family succession retirement option, as he retired from both management and ownership. His younger cousin, who had a conflict-free relationship with Pierre, was the natural successor and took over the full management and ownership of the business. In his case, at the business level, Pierre had a business partner he could rely on. However, he explained that during his first retirement year, he would think a lot about his business, wake up as if to go for work, and visit his bakery very often. He stopped visiting his bakery several times a week after one year. At the relational level, Pierre benefited from support from his spouse, who helped him realize that he had not really retired during his first year, given his frequent visits.

By the time $4 \frac{1}{2}$ years passed, Pierre was working at the bakery only occasionally -- to support his volunteer effort at his church's pastry sale. He is very careful to limit his involvement with the business, though. When asked about his well-being since retirement, he explains: "At some point, you need to say no, otherwise work continues and nothing changes...It's important to realize that you are doing something new in retirement... to grow older in a different way...Now I need to get used to being somebody else, elsewhere" (Froidevaux, 2018, p. 97).

\section{Conclusion}

Our framework (Alterman et al., 2020) highlights the unique aspects of small business owner retirement by considering how retirement decisions are made in tandem with business exit decisions. We identify unique predictors of the four retirement options and emphasize how these options vary based on "proximity," or how closely the owner remains involved in the business after retirement. We also propose that these options have important implications for business owners' psychosocial and financial well-being after retirement. Although other relevant factors are likely to shape a business owners' retirement decision -- such as health concerns, changes in family circumstances, and shifts in the industry -- our framework offers insight on the main retirement options, their common antecedents, and the psychosocial and financial outcomes related to each. Retiring is a difficult decision for most small business owners, but our model should help them select an option 
that fits their individual needs and desires.

\section{References}

Alterman, V., Froidevaux, A., Fasbender, U., \& Xie, J. (2020). A conceptual model of small business owners' unique retirement decisions: Multilevel antecedents and retirement adjustment consequences. Work, Aging and Retirement, 6(3), 146-152. https://doi.org/10.1093/workar/waaa010

Atchley, R. C. (1989). A continuity theory of normal aging. The Gerontologist, 29, 183-190.

Balcaen, S., Manigart, S., Buyze, J., \& Ooghe, H. (2012). Firm exit after distress: Differentiating between bankruptcy, voluntary liquidation and M\&A. Small Business Economics, 39, 949-975.

Biery, M. E. (2017, February 5). Study shows why many business owners can't sell when they want to. Forbes.com. Retrieved October 12021 from https://www.forbes.com/sites/sageworks/2017/02/05/th ese-8-stats-show-why-many-business-owners-cant-sellwhen-they-want-to/?sh=73d90b4a44bd

DeTienne, D. R. (2010). Entrepreneurial exit as a critical component of the entrepreneurial process: Theoretical development.Journal of Business Venturing, 25, 203-215.

https://doi.org/10.1016/j.jbusvent.2008.05.004

DeTienne, D. R., McKelvie, A., \& Chandler, G. N. (2015). Making sense of entrepreneurial exit strategies: A typology and test.Journal of Business Venturing, 30, 255-272.

https://doi.org/10.1016/j.jbusvent.2014.07.007

Exit Planning Institute. (2013, November). State of owner readiness survey results [Website].

\section{Owner-Readiness-Survey-2013-Presentation.pdf}

Froidevaux, A. (2018). A life design perspective on the work to retirement transition. In V. Cohen-Scali, J. Rossier, \& L. Nota (Eds.), New Perspectives on Career Counseling and Guidance in Europe (pp. 89-104). Springer.

Gómez-Mejía, L. R., Hoskisson, R. E., Makri, M., Sirmon, D. G., \& Campbell, J. (2011). Innovation and the preservation of socioemotional wealth in family controlled high technology firms. Unpublished manuscript, Texas A\&M University, College Station.

Knott, A., \& McGrath, R. (2004). Oiling the hinges on your exit strategy. Business Week Online, http://www.businessweek.com/smallbiz/content/aug200 4/sb2004083_3525_sb005.htm.

Lee, K. S., Lim, G. H., \& Lim, W. S. (2003). Family business succession: Appropriation risk and choice of successor. Academy of Management Review, 28, 657-666. https://doi.org/10.5465/AMR.2003.10899446

Mitchell, W. (1994). The dynamics of evolving markets, the effects of business sales and age on liquidations and divestitures.Administrative Science Quarterly, 39, 575-602.

Morris, M. H., Soleimanof, S., \& White, R. J. (2018). Retirement of entrepreneurs: Implications for entrepreneurial exit. Journal of Small Business Management, $\quad 58, \quad 1-24$. https://doi.org/10.1111/jsbm.12476

Neubauer, H. (2003). The dynamics of succession in family businesses in Western European countries. Family Business Review, 16, 269-281.

https://doi.org/10.1177/08944865030160040501

Pierce, J. L., Kostova, T., Dirks, K. T. (2001). Toward a theory of psychological ownership in organizations. Academy of Management Review, 26, 298-310.

Raymo, J. M., \& Sweeney, M. M. (2006). Work-family conflict and retirement preferences. The Journal of Gerontology: Series B, 61, S161-S169. https://doi.org/10.1093/geronb/61.3.S161

Sharma, P., Chrisman, J. J., \& Chua, J. H. (2003). Predictors of satisfaction with the succession process in family firms. Journal of Business Venturing, 18, 667-687.

Wang, M., \& Shultz, K. S. (2010). Employee retirement: A review and recommendations for future investigation. Journal of Management, 36, 172-206. https://doi.org/10.1177/0149206309347957

Wang, M., Henkens, K., \& van Solinge, H. (2011). Retirement adjustment: A review of theoretical and empirical advancements. American Psychologist, 66, 
204-213. https://doi.org/10.1037/a0022414

Wennberg, K., Wiklund, J., DeTienne, D. R., \& Cardon, M. S. (2010). Reconceptualizing entrepreneurial exit: Divergent exit routes and their drivers. Journal of Business Venturing, 25, 361-375. https://doi.org/10.1016/j.jbusvent.2009.01.001 